\title{
NATCHNIENIE \\ W DIACHRONICZNIE UJMOWANYM CIELE CHRYSTUSA. PRZYCZYNEK DO EKLEZJOLOGII NATCHNIENIA
}

\author{
INSPIRATION IN THE DIACHRONICALLY UNDERSTOOD BODY OF CHRIST: \\ CONTRIBUTION TO THE ECCLESIOLOGY OF INSPIRATION
}

\begin{abstract}
A bstract. The paper contributes to the theology of inspiration. The author draws conclusions regarding the biblical inspiration from contemporary ecclesiological thought presenting the Church as the Body of Christ. The Holy Spirit acted upon both the hagiographers included in the "we" of the Church (the New Testament) and those preparing the way for the future Body of Christ (the Old Testament). Inspiration was given to individuals, but for the sake of the community and through the influence of other members of the Body of Christ on the inspired authors. All biblical writers serve each other diachronically, too: the New Testament is not possible without the Old Testament hagiographers, while the Old Testament reveals its deepest meaning only within the New Testament fulfillment. The influence of the Holy Spirit on inspired authors should be seen in the framework of the communio sanctorum (the union of the earthly Church with the heavenly Church).
\end{abstract}

Keywords: biblical inspiration; ecclesiology of inspiration; the Body of Christ; the members of Christ; diachronic unity; communio sanctorum.

Jedną z dróg teologicznego opracowania natchnienia biblijnego wytyczył Karl Rahner, który ukazał związek natchnienia z założeniem Kościoła. Zdaniem niemieckiego jezuity natchnione pisma są istotną częścią tworzącego się Kościoła pierwotnego i jako takie stanowią razem z nim trwałą podstawę i normę. Jak Kościół pierwotny, tak i Biblia byłaby w niepowtarzalny sposób ustanowieniem Bożym ${ }^{1}$. Do koncepcji tej odwołał się Gerald O'Collins, ale

Dr SŁawomir Zatwardnicki — Papieski Wydział Teologiczny we Wrocławiu, Instytut Teologii Systematycznej i Duchowości, I Katedra Teologii Dogmatycznej; adres do korespondencji: ul. Katedralna 9, 50-328 Wrocław; e-mail: e-mail: zatwardnicki@gmail.com. ORCID: https:/orcid.org/ 0000-0001-7597-6604.

${ }^{1}$ Por. Karl Rahner, „Nowe ujęcie natchnienia biblijnego”, tłum. Anna Morawska, w: Biblia 
trudno uznać, że ją twórczo rozwiną ${ }^{2}$. Również dla Josepha Ratzingera ustanowienie kanonu i ustanowienie pierwotnego Kościoła byłyby w istocie tym samym procesem, tyle że oglądanym z różnych perspektyw ${ }^{3}$. Ze względu na związek Pisma z Kościołem istnieje między nimi jakieś trwałe podobieństwo, dlatego Telford Work wykorzystuje w swoim monumentalnym dziele związek refleksji eklezjologicznej z teologiczną refleksją nad Pismem Świętym (ang. bibliology) ${ }^{4}$ W niniejszym artykule podejmuję ten trop i przywołuję współczesną myśl eklezjologiczną, aczkolwiek ograniczoną do koncepcji Kościoła jako Ciała Chrystusa, w nadziei że przysłuży się ona do teologicznego pogłębienia rozumienia natchnienia biblijnego.

\section{CHARYZMAT NATCHNIENIA W CIELE CHRYSTUSA}

Jedynym ,egzegetą” niewidzialnego Boga jest widzialne Słowo Wcielone (por. J 1,18; 4,19; $1 \mathrm{~J} 4$,12; Kol 1,15), które jest nie tylko podmiotem Objawienia, ale i jego treścią ${ }^{5}$. „Misterium Boga jest bowiem ostatecznie niczym innym niż sam Chrystus - jest ono Osobą"6. Konsekwentnie przyjęcie Objawienia musi oznaczać wejście w relację z Chrystusem. Autorzy biblijni piszą o „Chrystusie w nas” i o „my w Chrystusie”. Mówiąc językiem Josepha Ratzingera, „całą rzeczywistością” czy „samym Objawieniem” jest tajemnica Chrystusa, która poprzedza natchnione eksplikacje zarówno jako

dzisiaj, red. Józef Kudasiewicz (Kraków: Wydawnictwo Znak, 1969), 189-197; Joseph Ratzinger, Wiara w Piśmie i Tradycji. Teologiczna nauka o zasadach, thum. Jarosław Merecki, Opera omnia, t. 9/2 (Lublin: Wydawnictwo KUL, 2018), 678. Zob. również podsumowanie koncepcji Rahnera w: Sławomir Stasiak, „Czy Kościół może obawiać się odkrycia nieznanych dotąd pism natchnionych?”, Wrocławski Przegląd Teologiczny 2 (2013): 60-61.

${ }^{2}$ Gerald O'Collins, Inspiration: Towards a Christian Interpretation of Biblical Inspiration (Oxford: Oxford University Press, 2018), 126-127; tenże, Revelation: Towards a Christian Interpretation of God's Self-revelation in Jesus Chris (Oxford: Oxford University Press, 2016), $163-164$.

${ }^{3}$ Por. Joseph Ratzinger, Wiara w Piśmie $i$ Tradycji. Teologiczna nauka o zasadach, tłum. Jarosław Merecki, Opera omnia, t. 9/1 (Lublin: Wydawnictwo KUL, 2018), 457; Scott Hahn, Przymierze i komunia. Teologia biblijna papieża Benedykta XVI, tłum. Dominika Krupińska (Kraków: Wydawnictwo Esprit, 2021), 61.

${ }^{4}$ Telforfd Work, Living and Active: Scripture in the Economy of Salvation (Grand Rapids: William B. Eerdmans Publishing Company, 2002), 218, 260.

${ }^{5}$ Por. Benedykt XVI, Verbum Domini, 90 [dalej cyt. VD].

${ }^{6}$ Joseph Ratzinger, O nauczaniu II Soboru Watykańskiego. Formułowanie - Przekaz Interpretacja, tłum. Ewa Grzesiuk, Opera omnia, t. 7/2 (Lublin: Wydawnictwo KUL, 2016), 654. Por. Sobór Watykański II, Konstytucja dogmatyczna o Objawieniu Bożym Dei verbum, nr 2 [dalej cyt. DV]. 
sama w sobie, jak i jako obecność istniejąca w wierzącym ${ }^{7}$. Chodzi tutaj nie tylko o uprzedniość logiczną, ale i chronologiczną - przyjęte przez adresata Objawienie w Chrystusie jest wcześniejsze od jego natchnionego przekazu. (Choć, trzeba dodać gwoli ścisłości, już po spisaniu natchnionej literatury Bóg może objawiać się również przez nią, a zatem „później” od samego natchnienia). Charyzmat natchnienia wiąże się wobec tego z życiem hagiografa w Chrystusie oraz z życiem Chrystusa w „my”, którego pisarz natchniony jest częścią. Chrystus pozostaje Objawieniem przez swoje Ciało, czyli Kościół $1^{8}$. Dar natchnienia może zatem funkcjonować najpełniej w Kościele będącym Ciałem Chrystusa ożywianym Duchem Świętym, a w Starym Testamencie o tyle, o ile wspólnota wierzących jako pozostająca w związku z Ludem Bożym Nowego Testamentu - służy przyszłemu Ciału.

Walter Kasper postrzega Kościół ,jako jeden lud Boży, który zarówno na płaszczyźnie synchronicznej, jak i diachronicznej ogarnia wszystkie przestrzenie i wszystkie czasy”. Osobista wiara chrześcijanina ,jest zawsze wiarą katolicką, która ma udział w jednej, wspólnej drodze wiary Kościoła wszystkich czasów i przestrzeni"”. Gdy niemiecki teolog pisze o Kościele jako Ciele Chrystusa, również podkreśla, że określenie to wyraża „synchroniczną i diachroniczną jedność Kościoła wszystkich miejsc i czasów"10. To Chrystus, jak przypomina się $\mathrm{w}$ konstytucji Lumen gentium, „udzielając [...] swego Ducha, ukształtował swoich braci wezwanych spośród wszystkich narodów jako swoje Mistyczne Ciało" ". Nie kto inny jak sam Chrystus jest tym, który gromadzi ludzi w jeden Lud, a ostatecznie w swoje Ciało.

Trzeba zatem w drodze ludu Starego Przymierza widzieć początek procesu, który zmierza do utworzenia (w „pełni czasu” - por. Ga 4,4) Kościoła jako Chrystusowego Ciała. Hagiografowie byliby tymi, przez których Bóg przygotował i umożliwił zaistnienie przyszłego Ciała. Gdy na ten proces spojrzeć z perspektywy Ludu Bożego odnowionego w Ciele Chrystusa wtedy przekonanie Ratzingera, że hagiografowie Starego Testamentu już

\footnotetext{
${ }^{7}$ Por. Ratzinger, Wiara w Piśmie i Tradycji, Opera omnia, t. 9/1, 359-360; Grzegorz Bachanek, „Sakramentalna struktura Słowa Bożego w teologii kard. J. Ratzingera”, Verbum Vitae 7(2005): 224.

${ }^{8}$ Por. Joseph Ratzinger, O nauczaniu II Soboru Watykańskiego. Formułowanie - Przekaz Interpretacja, thum. Wiesław Szymona, Opera omnia, t. 7/1 (Lublin: Wydawnictwo KUL, 2016), 549; Andrzej Czaja, „Naczelna zasada i przewodnie idee teologii Josepha Ratzingera”, Forum Teologiczne 8 (2007): 15.

${ }^{9}$ Walter Kasper, Kościót katolicki. Istota, rzeczywistość, posłannictwo, thum. Grzegorz Rawski (Kraków: Wydawnictwo WAM, 2014), 231.

${ }^{10}$ Kasper, Kościót katolicki, 240.

${ }^{11}$ Sobór Watykański II, Konstytucja dogmatyczna o Kościele Lumen gentium, nr 7 (dalej cyt. LG).
} 
należeli w pewien sposób do przyszłego Ciała Chrystusowego - zyskuje uzasadnienie $^{12}$. Należy oczywiście zachować rozróżnienie między uczestnictwem w Ciele w Nowym Przymierzu a łaską jakiegoś misteryjnego (i antycypacyjnego) włączenia w przyszłe Chrystusowe Ciało na etapie Starego Przymierza. Z pewnością możemy powiedzieć, że nie ma bez pisarzy natchnionych Starego Testamentu wspólnej drogi wiary, jednej i tej samej od początku aż do wypełnienia się historii zbawienia.

Gerhard Ludwig Müller utrzymuje, że „historia objawienia, zwłaszcza kiedy ma stać się powszechną, potrzebuje ludu wybranego jako zapewniającego ciągłość i tożsamość historii wiary, w której ukazuje się objawienie"13. Tylko dzięki temu jest możliwe, że Objawienie pozostaje obecne w późniejszej historii, a przez to Bóg może wypełniać swój plan względem ludzkości. I jeszcze więcej: dopiero tożsamość Ludu Bożego — tego samego w ciągu całej historii zbawienia i Objawienia — w ogóle umożliwia Bogu objawienie się; gdyby nie ciągłość wspólnoty wiary, Bóg musiałby objawić się „od razu” pierwszemu pokoleniu, a następnie ponawiać to objawienie każdej następnej generacji. Nie byłoby to możliwe, również z tego powodu, że w ten sposób ludzka wolność (i bazujące na niej odejście od Boga) zostałyby zanegowane. Dopiero wzajemnie naświetlające się ingerencje Boga (słowa i czyny, następnie zaświadczone w natchnionych pismach) mogły doprowadzić do sytuacji, w której kulminacyjne Objawienie w posłanym Synu mogło dojść do skutku i zostać rozpoznane.

W teologii natchnienia należy uwzględnić otwartość słowa ludzkiego, które wyraża więcej, niż mogłoby to mieścić się $\mathrm{w}$ intentio auctoris ${ }^{14}$. W wyniku relektur dokonywanych w Ludzie Bożym ukryte potencjalności słowa biblijnego - jako świadectwa zawsze większego Objawienia, a w szczególności jako świadectwa możliwości przyjęcia Objawienia w danym momencie dziejów zbawczych - mogły zostać wydobyte i rozwinięte ${ }^{15}$. Na tej drodze Pisma

\footnotetext{
${ }^{12}$ Por. Ratzinger, Wiara w Piśmie i Tradycji, Opera omnia, t. 9/1, 627. Warto przypomnieć, że obok szczególnej historii zbawienia rozpoczynającej się od Abrahama - istnieje również powszechna historia zbawienia, tak że ostatecz - por. LG 2; Kasper, Kościół katolicki, 226-227; Augustyn, Sermones 341, 9, 11. PL 39, 1499-1500.

${ }^{13}$ Gerhard Ludwig Müller, Dogmatyka katolicka, tłum. Wiesław Szymona (Kraków: Wydawnictwo WAM, 2015), 597. I odwrotnie, z zakorzenienia Objawienia biblijnego w historii wynika, że zamysł Boży musi odsłaniać się w niej stopniowo - VD 42.

${ }^{14}$ Por. Matthew Levering, Engaging the Doctrine of Revelation: The Mediation of the Gospel through Church and Scripture (Grand Rapids: Baker Academic, 2014), 81.

${ }^{15}$ Por. Joseph Ratzinger, Jezus z Nazaretu. Studia o chrystologii, tłum. Marzena Górecka i Wiesław Szymona, Opera omnia, t. 6/1 (Lublin: Wydawnictwo KUL, 2015), 124; tenże, Wiara w Piśmie i Tradycji, Opera omnia, t. 9/1, 330; Hahn, Przymierze i komunia, 136-137, 139.
} 
mogły ukazać istniejący w nich „naddatek sensu” będący wynikiem działania Ducha Świętego i zarazem, paradoksalnie, tak otwartości, jak i ograniczoności ludzkiej mowy ${ }^{16}$. Nie tylko zresztą o „kenotyczność” języka chodzi, lecz o grzech sprawiający, że Bóg nie może być inaczej poznawany niż równocześnie z procesem zbawienia człowieka; dlatego Objawienie musi być historyczne, a nie ponadczasowe, bo objawiający się Bóg w historii Ludu Bożego przekonuje o grzechu i potrzebie zbawienia — i w ten sposób przygotowuje możliwość przyjęcia pełni tak Objawienia, jak i zbawienia w Chrystusie.

Gdyby nie kenotyczny charakter ludzkiej mowy, Bóg musiałby wypowiedzieć się w całości „od razu”, czyli w istocie — zamilczeć, bo oczywiście Stwórca nieskończenie przekracza możliwości wysłowienia Jego tajemnicy w języku stworzeń. Uniżenie zatem Boga w słowie biblijnym jest konieczne nie tylko ze względu na grzech. $\mathrm{Z}$ kolei tylko dzięki tej kenozie słowa Bożego jako słowa Boga przekazanego w ludzkiej mowie - jest możliwe wywyższenie słowa Bożego, dzięki unii jednego z drugim sprawionej przez Ducha Świętego (analogia inkarnacyjna) ${ }^{17}$. To wywyższenie (tożsame $\mathrm{z}$ usłyszeniem) słowa Bożego jest jednak możliwe tylko wtedy, gdy Duch Święty pozwoli wierzącemu (wspólnocie wiary) przekroczyć ludzkie słowo i „sięgnąć” Boskiego (transcendencja słowa, o której pisał Ratzinger ${ }^{18}$ ).

\section{JEDNOSTKOWO-WSPÓLNOTOWY CHARAKTER NATCHNIENIA}

Autorzy natchnieni Nowego Testamentu otrzymywali Ducha Świętego w związku z ich przynależnością do Ludu Bożego oraz ze względu na służbę wspólnocie wiary. Owszem, byli inspirowani jako jednostki, ale kierował nimi ten sam Duch Święty, który jest Duchem zamieszkującym w całym Ciele Jezusa Chrystusa. Wolno zatem mówić, że autorem Pisma jest Kościół,

Na przykład Księgi Kronik na nowo opowiadają przedwygnaniowe historie zapisane w Księgach Samuela oraz Królewskich po to, by mogły one zwracać się do ludzi i stanowić dla nich wyzwanie w nowym kontekście - por. John Goldingay, Models for Interpretation of Scripture (Toronto: Clements Publishing, 2004), 123.

${ }^{16}$ Por. Ratzinger, Wiara w Piśmie i Tradycji, Opera omnia, t. 9/2, 718; Hahn, Przymierze i komunia, 137-138.

${ }^{17}$ Por. Sławomir Zatwardnicki, „An Incarnational Analogy That Is Hard to Escape From. A Polemic with James Prothro", Collectanea Theologica 91 (2021): 37-75.

${ }^{18}$ Por. Ratzinger, Jezus z Nazaretu, Opera omnia, t. 6/1, 126; tenże, Wiara $w$ Piśmie i Tradycji (Opera omnia, t. 9/2), 942. 
tyle że jest nim za pośrednictwem wybranych w tym celu poszczególnych członków ${ }^{19}$. Przy tym również sami hagiografowie pozostawali pod wpływem nie tylko wspólnego całemu Ciału Ducha, czerpiąc wprost od Niego, ale również korzystali z różnorodnych darów Ducha Świętego obdarzającego poszczególne (wszystkie - por. 1 Kor 12,11) członki Chrystusa. Dar natchnienia należy zatem sytuować w ramach wzajemnego służenia sobie darami - Duch działa również (albo przede wszystkim - i tego nie należy wykluczyć) przez pośrednictwo ludzkie. Na pierwszym miejscu zapewne w tym oddziaływaniu na hagiografa należałoby wyróżnić dar apostolski (por. Ef $2,20 ; 4,11)$, z którym charyzmat natchnienia jest szczególnie mocno związany.

Podkreślmy zatem, że nie tylko charyzmat natchnienia służy wspólnocie, ale już w samym fenomenie natchnienia powinno się uwzględnić wzajemną służbę członków sobie nawzajem. $Z$ jednej strony charyzmat musi być dany jednostce, jeśli dar ten ma służyć wspólnocie, z drugiej strony musi być społeczny, jeśli nie mamy zaprzeczyć, że Ducha Świętego otrzymujemy nie inaczej niż w Kościele i przez Kościól, który w całości i w każdym poszczególnym członku został napełniony Duchem Świętym ${ }^{20}$. Podobnie, a zarazem różnie trzeba podchodzić do natchnienia starotestamentalnego. Tam również charyzmat udzielony jednostce a w służbie całości nie byłby możliwy bez wzajemnych interakcji między pisarzem natchnionym a wspólnotą Ludu Bożego. Na uwagę zasługuje zwłaszcza, dostrzegalny już w samym Piśmie Świętym, inspirujący wpływ jednych autorów natchnionych na innych ${ }^{21}$. Dodatkowo hagiografowie Starego Przymierza, nawet jeśli nie byli świadomi tego, że piszą dla przyszłych pokoleń, działali również dla ich dobra, a nawet więcej: służyli przyszłemu Ciału Chrystusa, w którego życiu ich pisma odgrywać będą niezastępowalną rolę.

Hagiograf Nowego Testamentu korzystał z pewnością ze zmysłu wiary, jakim wszyscy wierni zostali obdarzeni na skutek wylania Ducha Świętego: po pierwsze, sensus fidei stał się również jego udziałem, po drugie zaś charyzmat natchnienia udzielony osobiście pisarzowi natchnionemu łączył się ze zmysłem wiary otrzymanym przez innych wiernych, którzy $\mathrm{w}$ ten sposób również dla hagiografa stawali się „prorokami”. Na ten szczególny aspekt zmysłu wiary zwróciła uwagę Międzynarodowa Komisja Teologiczna,

\footnotetext{
${ }^{19}$ Por. Ratzinger, O nauczaniu II Soboru Watykańskiego, Opera omnia, t. 7/1, 180-181.

${ }^{20}$ Por. Katechizm Kościoła katolickiego (Poznań: Wydawnictwo Pallottinum, 2009), nr 797 (dalej cyt. KKK); Pius XII, Encyklika Mystici Corporis Christi, nr 45 (DH 3808).

${ }^{21}$ Por. Papieska Komisja Biblijna, Natchnienie i prawda Pisma świętego. Stowo, które od Boga pochodzi i mówi o Bogu, aby zbawić świat, thum. Henryk Witczyk (Kielce: Verbum, 2014), nr 56.
} 
według której sensus fidei to „nadnaturalny zmysł, nierozerwalnie połączony z darem wiary, który wierni otrzymują we wspólnocie Kościoła, a który umożliwia chrześcijanom wypełnianie ich prorockiego powołania"22. Zdolność ta pochodzi od Ducha Świętego, który włącza ochrzczonych w prorocki urząd Chrystusa, udzielając im namaszczenia oraz osobistego, wewnętrznego przeżywania i pojmowania wiary Kościoła. Ostatecznie to Kościół jako całość pozostaje nieomylny w sprawach wiary, stąd nie wolno rozdzielać osobistego od wspólnotowego aspektu sensus fidei (por. SF 1; 7; 48-49; 54). Dlatego też Kościół jako całość kanonizował natchnione pisma - w sensie: rozpoznał, że pochodzą od Ducha Świętego; ten sam Duch Święty działał tak w autorach natchnionych (natchnienie), jak i we wspólnocie (namaszczenie wszystkich wiernych), do której kierowali przesłanie (zarazem swoje, jak i Ducha, który udzielił im swojego natchnienia - por. DV 11).

Już na etapie Starego Przymierza widać wyraźnie wspólnotowy wymiar natchnienia - choćby $\mathrm{w}$ tak podkreślanych przez Ratzingera relekturach prowadzących do coraz to nowych redakcji ksiąg. W ten sposób pojedyncze autorstwo relatywizuje się i, zdaniem Ratzingera, Duch Święty działa przede wszystkim właśnie w procesie przekraczania, oczyszczania i wzrostu ${ }^{23}$. Decydujący głos miałaby tutaj wspólnota - podmiot zachowujący tożsamość w wędrówce przez dzieje - do której słowo Boże zostało skierowane i która na słowo to musi odpowiedzieć. Jeśli zaś chodzi o „pojedyncze autorstwo" (które następnie zostało „zrelatywizowane”), to nawet ono nie było samo w sobie pierwszym źródłem prowadzącym do natchnionych ksiąg, bowiem pojedynczy autor należał do Ludu Bożego prowadzonego przez Boga i tylko w jego wierze mógł zaświadczyć o historycznych doświadczeniach tego ludu; również wtedy, gdy Bóg kierował słowo do „pośrednika” (np. proroka), czynił to przecież ze względu na przymierze $\mathrm{z}$ całym ludem, które ukształtowało proroka. Ponieważ hagiograf czerpał ze wspólnej historii, w dalszym ciągu prowadzonej przez Boga, w natchnionych pismach były obecne możliwości przyszłej drogi. Stąd Ratzinger mógł pisać, że zakres i głębia natchnionego słowa wychylają się tak w przeszłość, jak i w przyszłość ${ }^{24}$.

\footnotetext{
${ }^{22}$ Międzynarodowa Komisja Teologiczna, Sensus fidei w życiu Kościoła, tłum. Maria Moskal (Kraków: Wydawnictwo Księży Sercanów Dehon, 2015), nr 2 [dalej cyt. SF]. Zmysł wiary to swego rodzaju zmysł duchowy wyczulający na sprawy wiary - por. Gerald O'Collins i Edward G. Farrugia, „Sensus fidelium”, w: Leksykon pojęć teologicznych $i$ kościelnych z indeksem angielsko-polskim, tłum. Jan Ożóg i Barbara Żak (Kraków: Wydawnictwo WAM, 2002), 296.

${ }^{23}$ Por. Ratzinger, Wiara w Piśmie i Tradycji, Opera omnia, t. 9/2, 942.

${ }^{24}$ Por. Denis Farkasfalvy, ,Jesus of Nazareth and the Renewal of New Testament Theology”, Communio (wyd. ang.) 3 (2007): 440-441.
} 
W Nowym Przymierzu wszyscy zostali ochrzczeni w Duchu Świętym, a przez współudział w eucharystycznym Ciele Pańskim stają się jednym Ciałem w Chrystusie. Mistyczne Ciało Chrystusa jest rzeczywistością pneumatologiczną, w którą wchodzi się przez bramę sakramentów ${ }^{25}$. Być może już samo to tłumaczy stosunkowo szybki proces wykształcenia się pism nowotestamentalnych. Nie potrzeba było tutaj długiej historii relektur, prowadzących do wzrostu, ale i korekty poprzednich wypowiedzi; Duch Święty nie działa teraz fragmentarycznie przez różnych ludzi, których przekazy następne pokolenia muszą uzupełniać i korygować, lecz całościowo i od razu. Jest ciekawe, że teksty nowotestamentalne, nawet jeśli wyszły spod ręki nie jednego tylko autora, ale również zgromadzonej wokół niego „szkoły” (jak np. dziedzictwo Janowe), potem nie podlegają już korektom czy nawet relekturom. Uzyskawszy swoją ostateczną postać, będą potem interpretowane przez wszystkie czasy Kościoła bez dokładania czy odejmowania czegokolwiek (por. Ap 22,18-19). W Starym Testamencie, pomimo oddziaływania Ducha Świętego na pisarzy, poruszają się oni nieraz „po omacku”26 - i również w tym należy dostrzec przejaw łaskawego zniżenia się (łac. condescensio $^{27}$ ) Boga do ludzi ${ }^{28}$, który także w ten sposób potrafi wypowiedzieć słowo Boga.

Również świadomość spełnienia się obietnicy wypowiedzianej przez proroka Joela pozwala zrozumieć stosunkowo krótki okres wyłaniania się natchnionych pism Nowego Testamentu. Jeśli w okresie Starego Przymierza konieczna była praca kolejnych generacji wierzących, to w Nowym Przymierzu wszystko dzieje się praktycznie w ciągu jednego, dwóch pokoleń; tam diachronia, tu synchronia. Przepowiadanie apostolskie, które w swojej istocie było słowem Bożym (por. 1 Tes 2,13), mogło jedynie „przypadło-

${ }^{25}$ Por. Kasper, Kościót katolicki, 232-233; Müller, Dogmatyka katolicka, 604.

${ }^{26}$ Świadczy o tym choćby fakt, że Jezus nie spełnia wszystkich mesjańskich oczekiwań, np. dotyczących królewskiego mesjasza mającego być wojownikiem prowadzącym do restoracji Izraela - por. James D.G. Dunn, „Biblical Concepts of Revelation”, w: Divine Revelation, red. Paul Avis (Eugene: Wipf \& Stock Publishers, 1997), 17.

${ }^{27}$ Por. DV 13; Jan Chryzostom, In Gen., Hom. 17, 1. PG 53, 134; James B. Prothro, „The Christological Analogy and Theological Interpretation: Its Limits and Use," Journal of Theological Interpretation 1 (2020): 102, 104, 113; Sławomir Zatwardnicki, Księgi natchione i ich interpretacja. Inspirujace przestanie Josepha Ratzingera - Benedykta XVI (Lublin: Wydawnictwo Academicon, 2021), 26, 43.

${ }^{28}$ Peter Enns w swojej monografii ukazuje liczne nieścisłości historyczne czy wręcz teologiczne, jakie znamionują Pismo Święte, a wynikają właśnie z kenotycznego działania Boga, który dostosowuje się do ludzi - por. Peter Enns, Inspiration and Incarnation: Evangelicals and the Problem of the Old Testament (Grand Rapids: Baker Academic, 2015), ix/x, 173. 
ściowo" potrzebować pewnych retuszów i być może również na tym polegała praca Ducha w hagiografie, którą określamy natchnieniem. Bez zbawienia w Chrystusie i wylania Ducha Świętego proces kolejnych relektur musiałby ciągnąć się w nieskończoność, bez nadziei na to, że słowo Boże naprawdę spełni to, co obiecało. Z kolei słowo Boże, które zniżyło się w Starym Przymierzu adekwatnie do sytuacji człowieka, dokonało już jednak jakiejś pracy, przynajmniej na tyle, że żywe słowo Boże mogło zostać posiane na tak przygotowaną glebę:

Zaiste, podobnie jak ulewa i śnieg spadają z nieba i tam nie powracają, dopóki nie nawodnią ziemi, nie użyźnią jej i nie zapewnią urodzaju, tak iż wydaje nasienie dla siewcy i chleb dla jedzącego, tak słowo, które wychodzi z ust moich, nie wraca do Mnie bezowocne, zanim wpierw nie dokona tego, co chciałem, i nie spełni pomyślnie swego posłannictwa. (Iz 55,10-11)

\section{DIACHRONICZNA SŁUŻBA CZŁONKÓW CHRYSTUSA}

Można by tutaj skorzystać $\mathrm{z}$ analogii maryjnej i w charyzmacie natchnienia dopatrywać się jakiegoś podobieństwa do uprzedniości łaski Niepokalanego Poczęcia. Jak Najświętsza Maryja Panna otrzymała szczególną łaskę i przywilej na mocy przewidzianych zasług Zbawiciela, by przez swoje fiat otworzyć drogę wcielającemu się Słowu i tym samym umożliwić zbawcze dzieło $^{29}$, tak charyzmat natchnienia byłby szczególnym darem danym autorowi natchnionemu ze względu na przyszłe zasługi Chrystusa, dzięki któremu to darowi hagiograf służyłby historii zbawienia (soteriologiczny wymiar natchnienia). Przyszła Matka Pana otrzymała swój przywilej od chwili poczęcia Ducha Świętego, by Ten mógł ją zacienić w czasie Zwiastowania, sprawiając poczęcie Syna Bożego (por. Łk 1,35). To zaś przysłużyło się przyszłemu zesłaniu Ducha Świętego na cały Kościół w dzień Pięćdziesiątnicy (por. Dz 2). Podobnie pisarze natchnieni Starego Testamentu otrzymywaliby Ducha Świętego na poczet przyszłego wylania Ducha Świętego na całą wspólnotę wierzących, którego jednym ze skutków byłoby wyłonienie się pism nowotestamentalnych.

W dokumencie soborowym poświęconym Kościołowi czytamy, że Bóg nie opuścił ludzi „po ich upadku w Adamie, dając im nieustannie pomoce do

\footnotetext{
${ }^{29}$ O tej „cyrkularności” łaski Bożej - zob. Aaron Riches, „Deconstructing the Linearity of Grace: The Risk and Reflexive Paradox of Mary's Immaculate Fiat”, International Journal of Systematic Theology 2 (2008): 179-194.
} 
zbawienia przez wzgląd na Chrystusa, Odkupiciela" (LG 2) będącego Pierworodnym wobec stworzenia (por. Kol 1,15). Wyłania się tutaj zagadnienie związku między Adamem a Chrystusem jako drugim Adamem, do którego często sięgała w swoich wypowiedziach Międzynarodowa Komisja Teologiczna ${ }^{30}$. Apostoł Paweł przedstawia Adama i Chrystusa (antytyp i typ) jako dwie wielkości, które determinują całą historię ludzkości ${ }^{31}$, solidarną z obu Adamami (por. 1 Kor 15,21-22.45-49; Rz 5,12-19). Paralelizm Adam-Chrystus daleki jest jednak od symetryzmu, gdyż Chrystusowe zbawienie przezwyciężyło tragizm Adamowego nieposłuszeństwa: „nieszczęsna historia «pierwszego Adama» osiągnęła swój kres, ponieważ «drugi Adam» do samego końca, bez najmniejszego cienia nieufności, zaufał Bogu, swemu Ojcu i Stwórcy"32. Dlatego, jak podkreśla komisja teologów, zbawcza solidarność z Chrystusem przewyższa solidarność z Adamem ${ }^{33}$, na co wskazuje zresztą sam apostoł frazą „o ileż bardziej” (por. Rz 5,17), odwracającą porządek rzeczywistości na korzyść Chrystusa ${ }^{34}$. Dlatego w ujęciu teologicznym (historiozbawczym) prawdziwy początek ludzkości jest reprezen-

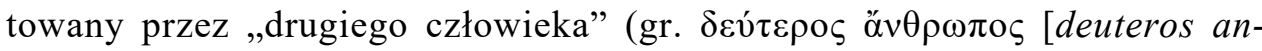
thrōpos] - 1 Kor 15,47), który dzierży prymat nad „pierwszym człowie-

\footnotetext{
${ }^{30}$ Por. Sławomir Zatwardnicki, „Teologiczna doniosłość typologii Adam-Chrystus na bazie dokumentów Międzynarodowej Komisji Teologicznej”, Teologia w Polsce 1 (2016): 205-224. $\mathrm{W}$ niniejszym akapicie korzystam $\mathrm{z}$ tej publikacji.

${ }^{31}$ Michael Ernst, „Adam-Chrystus typologia”, thum. Michał Szczepaniak, w: Nowy leksykon biblijny, red. Franz Kogler, Renate Egger-Wenzel, Michael Ernst, red. nacz. nauk. wyd. pol. Henryk Witczyk (Kielce: Wydawnictwo Jedność, 2011), 9. Kontrast Adam-Chrystus ukazuje również głęboką łączność między stworzeniem a odkupieniem - por. Gerald O’Collins, Jezus nasz Odkupiciel. Chrześcijańskie ujęcie zbawienia, tłum. Jan Pociej (Kraków: Wydawnictwo UJ, 2009), 37.

${ }^{32}$ Medard Kehl, I widziat Bóg, że to jest dobre. Teologia stworzenia, thum. Wiesław Szymona (Poznań: W drodze, 2008), 194. Jak pisał Ratzinger, przejście od egzystencji egoistycznej na wzór „pierwszego Adama” do życia służbą na model „drugiego Adama” jest możliwe dla człowieka jedynie dzięki „zastępstwu” Chrystusa. Wymiana między Chrystusem a grzesznikami zasadza się w nauce o dwóch Adamach - por. Joseph Ratzinger, Jezus z Nazaretu. Studia o chrystologii. Druga część tomu, tłum. Wiesław Szymona, Opera omnia, t. 6/2 (Lublin: Wydawnictwo KUL, 2016), 839-840.

${ }^{33}$ Międzynarodowa Komisja Teologiczna, Nadzieja zbawienia dla dzieci, które umieraja bez chrztu (2007), tłum. Janusz Królikowski (Kraków: Wydawnictwo Księży Sercanów Dehon, 2008), nr 91. Por. Międzynarodowa Komisja Teologiczna, Bóg Trójca, jedność ludzi. Monoteizm chrześcijański przeciwko przemocy (2014), tłum. Krzysztof Stopa (Kraków: Wydawnictwo Księży Sercanów Dehon, 2014), nr 51: „Nie ma podobieństwa między potęgą grzechu a potęgą łaski [...]. Nie tylko odkupieńcza moc łaski przerasta niszczącą siłę grzechu, ale jej skuteczność działa pod radykalnie innym znakiem".

${ }^{34}$ Międzynarodowa Komisja Teologiczna, „Teologia odkupienia” (1995), tłum. Zbigniew Morawiec, nr IV, 43, w: Od wiary do teologii, red. Janusz Królikowski (Kraków: Wydawnictwo Księży Sercanów Dehon, 2000).
} 


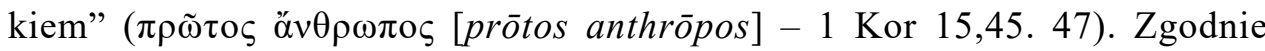
z orzeczeniem Synodu w Quierzy (853 r,) nie było i nie będzie takiego człowieka, za którego Chrystus nie cierpiał ${ }^{35}$. Jeśli jest możliwe uprzednie obdarzenie przyszłymi zasługami Chrystusa, czemu nie miałoby być możliwe udzielenie Ducha Chrystusowego hagiografom żyjącym w czasie Starego Przymierza? W każdym razie nowotestamentalny autor nie wahał się tego przywileju przyznać prorokom, zarazem zaznaczając właśnie prospektywność udzielonego daru:

Nad tym zbawieniem wszczęli poszukiwania i badania prorocy - ci, którzy przepowiadali przeznaczoną dla was łaskę. Badali oni, kiedy i na jaką chwilę wskazywał Duch Chrystusa, który w nich był i przepowiadał cierpienia [przeznaczone] dla Chrystusa i mające potem nastąpić uwielbienia. Im też zostało objawione, że nie im samym, ale raczej wam miały służyć sprawy obwieszczone wam przez tych, którzy wam głosili Ewangelię mocą zesłanego z nieba Ducha Świętego. Wejrzeć w te sprawy pragną aniołowie. (1 P 1,10-12)

Z kolei z odróżnienia charyzmatu natchnienia od niepokalanego poczęcia i darowanej Maryi pełni łaski wynikałyby konieczności: owego „przekraczania, oczyszczania i wzrostu", o których pisał Ratzinger, jak i dopełnienia kościelnego (Nowy Testament i późniejsza interpretacja pism w Kościele), bez którego słowo Boże nie mogłoby być „niepokalane”. Nie-niepokalaność hagiografów w połączeniu z niemożliwością przyjęcia pełni Objawienia przed „pełnią czasu” (Ga 4,4) wręcz domagała się kolejnych korekt ze strony Ludu Bożego, a ostatecznie Stary Testament dopiero z perspektywy Nowego może być świętym słowem Bożym. Charyzmat natchnienia w Starym Testamencie, właśnie jako łaska dana ze względu na przyszłe zasługi Chrystusa, pełnił rolę przygotowania do przyjęcia Słowa Bożego w przyszłości. Dar natchnienia zawsze jest związany z owocnością Chrystusowej Paschy, a jednocześnie służy realizowaniu się dokonanego odkupienia. W okresie Starego Testamentu charyzmat natchnienia był udzielany na zasadzie „paradygmatu niepokalanego poczęcia”, gdyż na danym etapie Objawienia i jego recepcji Lud Boży nie był jeszcze zdolny do przyjęcia pełni Objawienia. Dopiero w Nowym Przymierzu autorzy natchnieni jako członkowie wspólnoty zbawionych mogli otrzymać pełne światło na wydarzenie Chrystusa i tym samym na całe dzieje, które poza Barankiem pozostają „zapieczętowane”

\footnotetext{
${ }^{35}$ DH 624: „Christus Iesus Dominus noster, sicut nullus homo est, fuit vel erit, cuius natura in illo assumpta non fuerit, ita nullus est, fuit vel erit homo, pro quo passus non fuerit; licet non omnes passionis eius mysterio redimantur".
} 
(por. Ap 5,9). Ale, od drugiej strony, sam Baranek pozostałby nierozpoznany bez tekstów natchnionych Starego Przymierza.

W tym wszystkim, co do tej pory powiedzieliśmy, ukazuje się istotna cecha daru natchnienia. Jest to charyzmat, którym Duch posługuje się w całej historii zbawienia - dar duchowy, bez którego nie byłoby możliwe „wydarzenie Chrystusa" i jego skutki. Hagiografowie służą kolejnym pokoleniom, z kolei sami są przez nie odczytywani w nowy sposób w świetle postępujących dziejów zbawczych (chodzi tu zwłaszcza oczywiście o ich Chrystusowy szczyt). Natchnienie jest zatem jednym z darów we wzajemnej służbie realizującej się w Ciele Chrystusa. Przy tym Ciało wolno widzieć w perspektywie diachronicznej, w łączności z Ludem Bożym antycypującym to Ciało. Kościół jako Ciało Chrystusa pojawia się jako owoc Chrystusowej Paschy, ale przecież sięga nie tylko w przyszłość, lecz i w przeszłość właśnie na mocy łączności Ciała z Ludem Bożym. Poganie przez wiarę i chrzest znajdują się w Chrystusie, a dzięki temu, że jest On potomkiem obietnicy (por. $\mathrm{Rdz} 22,17$; Ga 3,16), oni również stają się członkami Ludu Bożego ${ }^{36}$. Wolno zatem mówić o tożsamości wspólnoty wierzących sięgającej całych dziejów zbawienia i Objawienia, Starego i Nowego Przymierza, i w związku z tym widzieć charyzmat natchnienia w jego wymiarze diachronicznym.

Jeśli przyjęcie Objawienia i zbawienia Chrystusowego nie było możliwe bez starotestamentalnego świadectwa, to z kolei święte pisma odziedziczone przez chrześcijan otrzymują swój najgłębszy sens dopiero wraz z interpretacją nadaną im w pierwotnym Kościele; w ten sposób zostają przeobrażone i dzięki temu zyskują trwałe znaczenie również w okresie Nowego Przymierza, szczególnie w kontekście liturgicznym, gdy słowa te są aktualizowane $^{37}$. Jest to jedna z odsłon wzajemnej służby wszystkich członków w Chrystusowym Ciele: ,jako dobrzy szafarze różnorakiej łaski Bożej służcie sobie nawzajem tym darem, jaki każdy otrzymał" (1 P 4,10). Konstytucja Lumen gentium odnosi to wezwanie hagiografa do udzielania sobie dóbr między Kościołami lokalnymi (LG 13), dzięki czemu poszczególne części Kościoła katolickiego „skutecznie przyczyniają się do dobra całego Mistycznego Ciała, które jest także wspólnym ciałem Kościołów" (LG 23). To synchroniczne ujęcie winno być dopełnione diachronicznym, i dlatego apostolską zachętę należy widzieć jako obejmującą wszystkich należących do Ludu Bożego w całym czasie jego istnienia (Stare i Nowe Przymierze):

\footnotetext{
${ }^{36}$ Por. Kasper, Kościót katolicki, 223-224, 232; Enns, Inspiration and Incarnation, 127.

${ }^{37}$ Por. Work, Living and Active, 174-175.
} 
Natomiast żyjąc prawdziwie w miłości sprawmy, by wszystko rosło ku Temu, który jest Głową - ku Chrystusowi. Z Niego całe Ciało - zespalane i utrzymywane w łączności dzięki całej więzi umacniającej każdy z członków stosownie do jego miary - przyczynia sobie wzrostu dla budowania siebie w miłości (Ef 4, 15-16) (por. LG 30).

Również dar natchnienia należy widzieć w diachronicznym ujęciu, jako działanie Ducha Świętego, które może przynieść zamierzony przez Boga owoc dopiero, gdy rozpatrywane jest w całej rozciągłości („natchnienie kanoniczne"). I w końcu należy również podkreślić eschatologiczną funkcję natchnienia, w którego efekcie powstały pisma służące aż do końca czasów budowaniu Ciała Chrystusa.

\section{DAR NATCHNIENIA A COMMUNIO SANCTORUM}

Jest interesujące, że także rola hagiografów jako autorów natchnionych pism, które zachowują swoją aktualność przez cały okres Kościoła, nie sprowadza się jedynie do przeszłości. Ciało jest przecież rzeczywistością ziemsko-niebiańską, obejmuje bowiem wszystkich posiadających Ducha Chrystusowego. Kościół jest przestrzenią panowania Chrystusa wywyższonego ponad niebo i ziemię i dlatego Kościół ziemski należy widzieć zawsze w jego związku z niebieskim (por. Ga 4,26; Ef 2,6), a już zwłaszcza w liturgii, która jest udziałem w niebiańskiej liturgii ${ }^{38}$. Konstytucja dogmatyczna o Kościele podkreśla nawet, że po śmierci wierzącego nie tylko że nie ustaje jego łączność z żyjącymi, ale wręcz wzrasta:

Wszyscy bowiem, którzy należą do Chrystusa, mając Jego Ducha, zrastają się w jeden Kościół i zespalają się wzajemnie ze sobą w Chrystusie (por. Ef 4,16). Łączność więc pielgrzymów z braćmi, którzy zasnęli w pokoju Chrystusa, bynajmniej nie ustaje; co więcej, według nieustannej wiary Kościoła jeszcze umacnia się dzięki wzajemnemu udzielaniu sobie dóbr duchowych. Dzięki bowiem temu, że mieszkańcy nieba głębiej są zjednoczeni z Chrystusem, jeszcze mocniej utwierdzają cały Kościół w świętości, podnoszą godność kultu Bożego, który Kościół sprawuje na ziemi, i na różne sposoby obracają na większe jego zbudowanie (por. 1 Kor 12,12-27). (LG 49; por. KKK 955)

Ta z gruntu katolicka wypowiedź, choć zasługuje na uznanie, nie była chyba do tej pory w ogóle brana pod uwagę w teologicznej refleksji nad Pismem

\footnotetext{
${ }^{38}$ Por. Kasper, Kościół katolicki, 178-179.
} 
Świętym czy hermeneutyką ksiąg natchnionych. W świetle doktryny katolickiej nie będzie przesadą stwierdzenie, że hagiografowie Starego Testamentu przyczynili się i przyczyniają się do chrześcijańskiego odczytania napisanych przez siebie, acz z inspiracji Ducha Świętego ksiąg. Ich zjednoczenie z Chrystusem sprawia, że wciąż - i to jeszcze mocniej niż za życia — służą oni pielgrzymującym na ziemi braciom. Nie należy redukować tego „udzielania sobie dóbr duchowych" ${ }^{39}$ jedynie do faktu, że pisarze natchnieni przyczynili się do powstania świętych pism, owszem wolno zgodzić się, że wciąż współpracują oni (wstawiennictwo świętych - por. KKK 956) w ich prawidłowej interpretacji. „Bo jak wzajemna komunia chrześcijańska między pielgrzymami prowadzi nas coraz bliżej do Chrystusa, tak obcowanie ze świętymi łączy nas z Chrystusem, z którego, jako ze Źródła i Głowy, wypływa wszelka łaska i życie Ludu Bożego" (LG 50; por. KKK 957).

Wiemy, że po swojej śmierci Chrystus przebywał w krainie zmarłych (por. 1 Kor 15,20). Ludzka dusza Jezusa - zjednoczona przecież z Boską Osobą (unia hipostatyczna!) — znalazła się pomiędzy zmarłymi, spomiędzy których został wywiedziony przez Boga (por. Hbr 13,20). „Zabity wprawdzie na ciele, ale powołany do życia Duchem”, w którym „poszedł ogłosić [zbawienie] nawet duchom zamkniętym w więzieniu" (1 P 3,18-19), czyli w Szeolu czy Otchłani (por. Rz 10,6; Ap 1,18). Dlatego autor natchniony pisze, że „nawet umarłym głoszono Ewangelię, aby wprawdzie podlegli sądowi jak ludzie w ciele, żyli jednak w Duchu - po Bożemu" (1 P 4,6) (por. KKK 632-634, 637). Wyznawane w Credo „zstąpienie do piekieł” jest według Katechizmu:

ostateczną fazą mesjańskiego posłania Jezusa, fazą skondensowaną w czasie, ale ogromnie szeroką w swym rzeczywistym znaczeniu rozciągnięcia odkupieńczego dzieła na wszystkich ludzi wszystkich czasów i wszystkich miejsc, ponieważ wszyscy ci, którzy są zbawieni, stali się uczestnikami Odkupienia. (KKK 634)

To „skondensowanie w czasie" w istocie w ogóle nie musi posiadać odzwierciedlenia na osi czasu - zauważa Piotr Liszka. Biblijne „trzy dni” byłyby, według polskiego teologa, raczej wyrażeniem mającym oddać głębię tajemnicy paschalnej i prawdziwość śmierci Jezusa. Zejście do Szeolu należałoby, zdaniem Liszki, przedstawić raczej w formie osi prostopadłej do osi biegnącego czasu, postawionej w punkcie śmierci Jezusa. Chrystus, schodząc aż do „dna” Otchłani, ogarnął całą przeszłość i przygarnął wszystkich

\footnotetext{
${ }^{39}$ Katechizm mówi o „komunii dóbr duchowych”, w tym o „komunii charyzmatów”, w kontekście Kościoła ziemskiego - por. KKK 949-953.
} 
ludzi, aż do Adama ${ }^{40}$. Nie musimy chyba zastanawiać się nad misterium przecinania się czasu z eschatologicznym „wydarzeniem Chrystusa” schodzącego do Szeolu i powstającego z martwych. Wystarczy powiedzieć, że „od naszej” strony, czyli z perspektywy osi biegnącego czasu, od momentu wyzwolenia przez Chrystusa tych sprawiedliwych, którzy Go poprzedzili (KKK 633), można spodziewać się również ich oddziaływania na cały czas Kościoła. To zaś oznacza, że pisarze Starego Testamentu w ramach świętych obcowania odgrywają rolę $\mathrm{w}$ interpretacji pisanych przez siebie ksiąg, a tym samym mają swój udział w powstaniu Nowego Testamentu oraz w dalszym jego oddziaływaniu we wspólnocie wierzących. Podobnie Apostołowie oraz hagiografowie Nowego Testamentu ${ }^{41}$ również przyczyniają się do genezy i wpływu świętych pism Nowego Przymierza. Można by zatem powiedzieć, że natchnienie, które jest darem Ducha Świętego, dociera również za pośrednictwem świętych obcowania.

Należy uznawać „tę komunię całego Mistycznego Ciała Jezusa Chrystusa” (LG 50) oraz doceniać, że „w najbardziej [...] szlachetny sposób nasze zjednoczenie z Kościołem niebieskim dokonuje się wtedy, kiedy szczególnie w świętej liturgii, w której moc Ducha Świętego działa na nas przez sakramentalne znaki - wspólnie z nim w radosnym uniesieniu wielbimy majestat Boży”, gdy „wszyscy odkupieni krwią Chrystusa z każdego pokolenia, języka, ludu i narodu (por. Ap 5,9) i zgromadzeni w jeden Kościół, jedną pieśnią chwały uwielbiamy Boga w Trójcy jedynego". Już Augustyn zauważał, że w Eucharystii jest obecny totus Christus, caput et membra, dlatego sakrament ten wiąże chrześcijanina tak z Głową, jak i z Mistycznym Ciałem (por. 1 Kor 10,17) ${ }^{42}$. Ojcowie Soboru podkreślają, że w czasie eucharystycznej Ofiary „najściślej niewątpliwie jednoczymy się ze czcią oddawaną Bogu przez Kościół niebieski, wchodząc w święte z nim obcowanie i czcząc pamięć przede wszystkim chwalebnej zawsze Dziewicy Maryi, a także św. Józefa, świętych Apostołów i męczenników oraz wszystkich świętych" (LG 50). Duch Święty, który działał przez hagiografów w czasie tworzenia Pisma, nie przestał tego czynić, gdy pisma natchnione są głoszone i interpretowane w Kościele. W ten sposób Słowo Boże wciąż dociera do nas przez pośrednictwo ludzkie, eklezjalne — tyle że nie

\footnotetext{
${ }^{40}$ Por. Piotr Liszka, Wplyw nauki o czasie na refleksję teologiczna. (Wplyw koncepcji czasu na refleksję teologiczna) (Warszawa: Wydawnictwo Palabra, 1992), 137.

${ }^{41}$ Zakładam możliwość świętych obcowania między pisarzami, którzy odeszli do Pana wcześniej, niż powstały późniejsze księgi Nowego Testamentu, a autorami tych drugich oraz pozostałą na ziemi wspólnotą wierzących.

${ }^{42}$ Por. Kasper, Kościót katolicki, 236.
} 
ograniczone do Kościoła ziemskiego. Nie do przecenienia będzie oczywiście wstawiennictwo Matki Bożej, która „w swym wniebowzięciu do niebieskiej chwały z duszą i ciałem jest światłem oświetlającym lud Boży w jego drodze przez czas" ${ }^{\prime 3}$. Do określenia Matki Kościoła przynależy prawdopodobnie również błogosławiony wpływ Wniebowziętej na zrodzenie się Nowego Testamentu z łona Kościoła ${ }^{44}$. Wypada, żeby Najświętsza Maryja Panna spełniła istotną rolę również $\mathrm{w}$ powstaniu świętych pism jako niezbędnego elementu składowego konstytuującego się Kościoła; tym samym wróciliśmy do Rahnerowskiego ujęcia ustanowienia Pism razem z ustanowieniem Kościoła.

\section{REKAPITULACJA}

Charyzmat natchnienia został udzielony wierzącym włączonym w życie Chrystusa przeżywane w „my” Kościoła. Dar natchnienia funkcjonuje najpełniej w Kościele będącym Ciałem Chrystusa ożywianym Duchem Świętym. W okresie Starego Testamentu dar ten operował o tyle, o ile Lud Boży służył przyszłemu Ciału. Bez świętych pisarzy Starego Testamentu nie można by mówić o wspólnej drodze wiary od początku aż do wypełnienia się historii zbawienia. Należy dostrzegać diachroniczną jedność Ludu Bożego gromadzonego przez Chrystusa. Objawienie pozostaje obecne w historii dzięki jednemu podmiotowi pielgrzymującemu przez całe dzieje. Teologia natchnienia zakłada otwartość słowa ludzkiego, poprzez które Bóg wypowiada się na sposób kenotyczny, który jednocześnie pozwala Mu wyrazić w słowie autorów natchnionych więcej, niż byli oni tego świadomi („naddatek sensu”). „Wywyższenie" słowa Bożego przekazanego za pośrednictwem ludzi jest możliwe dzięki unii sprawianej przez Ducha Świętego (analogia inkarnacyjna).

\footnotetext{
${ }^{43}$ Kasper, Kościót katolicki, 271. Por. LG 69: „Niechaj wszyscy wierni błagają wytrwale Matkę Boga i Matkę ludzi, aby Ta, która swymi modlitwami wspierała początki Kościoła, także $\mathrm{i}$ teraz $\mathrm{w}$ niebie, wywyższona ponad wszystkich świętych i aniołów, w komunii wszystkich świętych wstawiała się u swego Syna [...]".

${ }^{44}$ Por. VD 19, gdzie jest mowa o analogii między tym, że „Słowo Boże stało się ciałem za sprawą Ducha Świętego w łonie Dziewicy Maryi”, oraz tym, że „Pismo święte rodzi się z łona Kościoła za sprawą tegoż Ducha". Czesław Bartnik podaje dwie hipotezy dotyczące wieku życia Maryi — według pierwszej z nich Matka Boża w momencie śmierci Chrystusa miałaby ok. 42-46 lat i potem miałaby szybko (przed 50 rokiem życia) „zasnąć”, według drugiej miałaby ok. 60 lat, gdy Chrystus umierał, a potem żyłaby jeszcze około 20 lub więcej lat. Nawet druga z hipotez nie przekreśla wpływu Wniebowziętej na (przynajmniej część) świętych pisarzy. Por. Czesław Stanisław Bartnik, Dogmatyka katolicka, Tom II: Traktaty VII-XIII (Lublin: Wydawnictwo KUL, 2012), 383 .
} 
Natchnienie wiąże się z przynależnością do Ludu Bożego i służy wspólnocie. Hagiografowie byli inspirowani jako jednostki przez Ducha Świętego zamieszkującego w Ciele Chrystusa. Mistyczne Ciało Chrystusa jest rzeczywistością sakramentalno-pneumatologiczną, dlatego trzeba podkreślić udział autorów natchnionych w eucharystycznym Ciele Pańskim. Hagiografowie pozostawali pod wpływem Ducha Świętego, bezpośrednim oraz pośrednim, przez to, że czerpali z innych darów (zwłaszcza apostolskiego) udzielanych członkom Chrystusa. Święci pisarze korzystali również ze zmysłu wiary właściwego wszystkim wierzącym namaszczonym Duchem. Charyzmat natchnienia sytuuje się w ramach wzajemnej służby darami w Ciele Chrystusa. Należy go postrzegać w jego wymiarach indywidualnym i społecznym.

Zgodnie z ,paradygmatem Niepokalanego Poczęcia” charyzmat natchnienia był udzielany w okresie Starego Przymierza ze względu na przyszłe zasługi Chrystusa (teologiczne pierwszeństwo Adama drugiego przed pierwszym). W ten sposób obdarzony specjalnym darem hagiograf służył rozwijającej się historii zbawienia, przygotowując do przyjęcia Słowa Bożego w przyszłości. Duch Święty był im dany po to, żeby w „,pełni czasu” mogło nastąpić wylanie Ducha Świętego na cały Lud Boży (proroctwo Joela), czego jednym ze skutków będzie powstanie świętych pism Nowego Testamentu. Dopiero wraz z Nowym Przymierzem całe wcześniejsze dzieje zostają „rozpieczętowane” przez Baranka, z kolei On pozostałby nierozpoznany bez tekstów natchnionych Starego Przymierza. Natchnienie okazuje się jednym $\mathrm{z}$ darów we wzajemnej służbie realizującej się w Ciele Chrystusa, przy czym Ciało to należy widzieć w perspektywie diachronicznej, ogarniającej również Lud Boży Starego Testamentu. Dopiero to „kanoniczne”, całościowe ujęcie działania Ducha Świętego pozwala pogłębić teologię natchnienia.

Jeśli mistyczne Ciało Chrystusa jest rzeczywistością ziemsko-niebiańską, trzeba uwzględniać wpływ hagiografów na wspólnotę nie tylko przeszły, ale i teraźniejszy. Nie sprowadza się ich wkład jedynie do powstania świętych pism, ale również do ich interpretacji ( $\mathrm{w}$ tym zawiera się również nowotestamentalna interpretacja Starego Testamentu). W Ciele Chrystusa dokonuje się wzajemne udzielanie sobie dóbr duchowych, dlatego należy spodziewać się wstawiennictwa świętych pisarzy na kolejne pokolenia wierzących. Misterium „zstąpienia do piekieł” wyjaśnia, że również hagiografowie Starego Testamentu uczestnicą w tej szczególnej odsłonie świętych obcowania związanej z Pismem Świętym. Konsekwentnie w teologii natchnienia wziąć należy pod uwagę, że dar Ducha Świętego dociera również za pośred- 
nictwem przebywających w chwale zmarłych wcześniej hagiografów na kolejnych autorów natchnionych. Ich wpływ zaznacza się zwłaszcza w liturgii, jednoczącej Kościół pielgrzymujący i chwalebny, obejmuje zatem zapewne głoszenie słowa Bożego. Szczególnie owocnego wstawiennictwa należy spodziewać się ze strony Matki Bożej; Wniebowzięta, która służy Ludowi Bożemu w jego drodze, miała z pewnością również swój udział w zrodzeniu świętych pism z łona Kościoła.

\section{REFERENCJE}

Augustyn. Sermones 341, 9, 11. PL 39, 1499-1500.

Bachanek, Grzegorz. „Sakramentalna struktura Słowa Bożego w teologii kard. J. Ratzingera”. Verbum Vitae 7(2005): 215-229.

Bartnik, Czesław Stanisław. Dogmatyka katolicka. Tom II: Traktaty VII-XIII. Lublin: Wydawnictwo KUL, 2012.

Benedykt XVI. Posynodalna Adhortacja apostolska Verbum Domini do biskupów i duchowieństwa, do osób konsekrowanych i wiernych świeckich o Słowie Bożym w życiu i misji Kościoła. Rzym: Libreria Editrice Vaticana, 2010. Stolica Święta. Dostęp 10.01.2022 https://www. vatican.va/content/benedict-xvi/pl/apost_exhortations/documents/hf_ben-xvi_exh_20100930 verbum-domini.html

Czaja, Andrzej. „Naczelna zasada i przewodnie idee teologii Josepha Ratzingera”. Forum Teologiczne 8 (2007): 5-18.

Dunn, James D.G. „Biblical Concepts of Revelation”. W: Divine Revelation, red. Paul Avis, 1-22. Eugene: Wipf \& Stock Publishers, 1997.

Enns, Peter. Inspiration and Incarnation: Evangelicals and the Problem of the Old Testament. Grand Rapids: Baker Academic, 2015.

Ernst, Michael. „Adam-Chrystus typologia”. Tłum. Michał Szczepaniak. W: Nowy leksykon biblijny, red. Franz Kogler, Renate Egger-Wenzel i Michael Ernst, red. nacz. nauk. wyd. pol. Henryk Witczyk, 9. Kielce: Wydawnictwo Jedność, 2011.

Farkasfalvy, Denis. „Jesus of Nazareth and the Renewal of New Testament Theology”. Communio (wyd. ang.) 3 (2007): 438-453.

Goldingay, John. Models for Interpretation of Scripture. Toronto: Clements Publishing, 2004.

Hahn, Scott. Przymierze i komunia. Teologia biblijna papieża Benedykta XVI. Tłum. Dominika Krupińska. Kraków: Wydawnictwo Esprit, 2021.

Jan Chryzostom, In Genesim, Hom. 17, 1. PG 53, 134. Pol. Homilie na Ksiegę Rodzaju. Wprowadzenie, przekład i opracowanie Sylwia Kaczmarek. Źródła Myśli Teologicznej 45. Kraków: Wydawnictwo WAM, 2008.

Kasper, Walter. Kościót katolicki. Istota, rzeczywistość, posłannictwo. Tłum. Grzegorz Rawski. Kraków: Wydawnictwo WAM, 2014.

Katechizm Kościoła katolickiego. Poznań: Pallottinum, 2009.

Kehl, Medard. I widział Bóg, że to jest dobre. Teologia stworzenia. Tłum. Wiesław Szymona. Poznań: W drodze, 2008.

Levering, Matthew. Engaging the Doctrine of Revelation: The Mediation of the Gospel through Church and Scripture. Grand Rapids: Baker Academic, 2014. 
Liszka, Piotr. Wptyw nauki o czasie na refleksję teologiczna. (Wptyw koncepcji czasu na refleksje teologiczna). Warszawa: Wydawnictwo Palabra, 1992.

Międzynarodowa Komisja Teologiczna. „Teologia odkupienia” (1995). Tłum. Zbigniew Morawiec. W: Od wiary do teologii, red. Janusz Królikowski, 341-391. Kraków: Wydawnictwo Księży Sercanów Dehon, 2000.

Międzynarodowa Komisja Teologiczna. Bóg Trójca, jedność ludzi. Monoteizm chrześcijański przeciwko przemocy (2014). Tłum. Krzysztof Stopa. Kraków: Wydawnictwo Księży Sercanów Dehon, 2014.

Międzynarodowa Komisja Teologiczna. Nadzieja zbawienia dla dzieci, które umieraja bez chrztu (2007). Tłum. Janusz Królikowski. Kraków: Wydawnictwo Księży Sercanów Dehon, 2008.

Międzynarodowa Komisja Teologiczna. Sensus fidei w życiu Kościoła. Tłum. Maria Moskal. Kraków: Wydawnictwo Księży Sercanów Dehon, 2015.

Müller, Gerhard Ludwig. Dogmatyka katolicka. Tłum. Wiesław Szymona. Kraków: Wydawnictwo WAM, 2015.

O'Collins, Gerald. Inspiration: Towards a Christian Interpretation of Biblical Inspiration. Oxford: Oxford University Press, 2018.

O’Collins, Gerald. Jezus nasz Odkupiciel. Chrześcijańskie ujęcie zbawienia. Tłum. Jan Pociej. Kraków: Wydawnictwo UJ, 2009.

O'Collins, Gerald. Revelation: Towards a Christian Interpretation of God's Self-revelation in Jesus Christ. Oxford: Oxford University Press, 2016.

O'Collins Gerald, i Edward G. Farrugia. „Sensus fidelium”. W: Leksykon pojęć teologicznych $i$ kościelnych $z$ indeksem angielsko-polskim. Tłum. Jan Ożóg i Barbara Żak, 296. Kraków: Wydawnictwo WAM, 2002.

Papieska Komisja Biblijna. Natchnienie i prawda Pisma świętego. Słowo, które od Boga pochodzi i mówi o Bogu, aby zbawić świat. Tłum. Henryk Witczyk. Kielce: Verbum, 2014.

Pius XII. Encyklika Mystici corporis Christi o Mistycznym Ciele Jezusa Chrystusa i o naszym w nim zjednoczeniu z Chrystusem. 29.06.1943. Opoka.org.pl. Dostęp 10.01.2022. https:// opoka.org.pl/biblioteka/W/WP/pius_xii/encykliki/mystici_corporis_29061943.html

Prothro, James B. „The Christological Analogy and Theological Interpretation: Its Limits and Use.” Journal of Theological Interpretation 1 (2020): 102-119.

Rahner, Karl. „Nowe ujęcie natchnienia biblijnego”. Tłum. Anna Morawska. W: Biblia dzisiaj, red. Józef Kudasiewicz, 189-197. Kraków: Wydawnictwo Znak, 1969.

Ratzinger, Joseph. Jezus z Nazaretu. Studia o chrystologii. Tłum. Marzena Górecka i Wiesław Szymona. Opera omnia, t. 6/1. Lublin: Wydawnictwo KUL, 2015.

Ratzinger, Joseph. Jezus z Nazaretu. Studia o chrystologii. Tłum. Wiesław Szymona. Opera omnia, t. 6/2. Lublin: Wydawnictwo KUL, 2016.

Ratzinger, Joseph. O nauczaniu II Soboru Watykańskiego. Formułowanie - Przekaz - Interpretacja. Tłum. Wiesław Szymona. Opera omnia, t. 7/1. Lublin: Wydawnictwo KUL, 2016.

Ratzinger, Joseph. O nauczaniu II Soboru Watykańskiego. Formułowanie - Przekaz - Interpretacja. Tłum. Ewa Grzesiuk. Opera omnia, t. 7/2. Lublin: Wydawnictwo KUL, 2016.

Ratzinger, Joseph. Wiara w Piśmie i Tradycji. Teologiczna nauka o zasadach. Tłum. Jarosław Merecki. Opera omnia, t. 9/1. Lublin: Wydawnictwo KUL, 2018.

Ratzinger, Joseph. Wiara $w$ Piśmie i Tradycji. Teologiczna nauka o zasadach. Tłum. Jarsoław Merecki. Opera omnia, t. 9/2. Lublin: Wydawnictwo KUL, 2018.

Riches, Aaron. „Deconstructing the Linearity of Grace: The Risk and Reflexive Paradox of Mary's Immaculate Fiat". International Journal of Systematic Theology 2 (2008): 179-194. 
Sobór Watykański II. „Konstytucja dogmatyczna o Kościele Lumen gentium”. W: Sobór Watykański II. Konstytucje, dekrety, deklaracje. Tekst polski. Nowe thumaczenie, 104-163. Poznań: Pallottinum, 2002.

Sobór Watykański II. „Konstytucja dogmatyczna o Objawieniu Bożym Dei verbum”. W: Sobór Watykański II. Konstytucje, dekrety, deklaracje. Tekst polski. Nowe thumaczenie, 350-363. Poznań: Pallottinum, 2002.

Stasiak, Sławomir. „Czy Kościół może obawiać się odkrycia nieznanych dotąd pism natchnionych?”. Wrocławski Przegląd Teologiczny 2 (2013): 59-70.

Work, Telforfd. Living and Active: Scripture in the Economy of Salvation. Grand Rapids: William B. Eerdmans Publishing Company, 2002.

Zatwardnicki, Sławomir. „An Incarnational Analogy That Is Hard to Escape From: A Polemic with James Prothro". Collectanea Theologica 91 (2021): 37-75.

Zatwardnicki, Sławomir. „Teologiczna doniosłość typologii Adam-Chrystus na bazie dokumentów Międzynarodowej Komisji Teologicznej”. Teologia w Polsce 1(2016): 205-224.

Zatwardnicki, Sławomir. Ksiegi natchione i ich interpretacja. Inspirujace przesłanie Josepha Ratzingera-Benedykta XVI. Lublin: Wydawnictwo Academicon, 2021.

\section{NATCHNIENIE \\ W DIACHRONICZNIE UJMOWANYM CIELE CHRYSTUSA. PRZYCZYNEK DO EKLEZJOLOGII NATCHNIENIA}

\section{Streszczenie}

Niniejszy tekst stanowi przyczynek do teologii natchnienia. Autor wyprowadza wnioski dotyczące natchnienia biblijnego ze współczesnej myśli eklezjologicznej, ukazującej Kościół jako Ciało Chrystusa. Duch Święty działał na hagiografów włączonych w „my” Kościoła (Nowy Testament) lub przygotowujących drogę dla przyszłego Ciała Chrystusa (Stary Testament). Natchnienie zostało udzielone jednostkom, ale ze względu na wspólnotę i za pośrednictwem oddziaływania pozostałych członków Ciała Chrystusa na autorów natchnionych. Wszyscy biblijni pisarze służą sobie nawzajem także diachronicznie: Nowy Testament nie jest możliwy bez hagiografów Starego Testamentu, z kolei Stary Testament odkrywa swój najgłębszy sens dopiero wraz z nowotestamentalnym wypełnieniem. Oddziaływanie Ducha Świętego na autorów natchnionych należy postrzegać w ramach communio sanctorum oraz łączności Kościoła ziemskiego z niebieskim.

Słowa kluczowe: natchnienie biblijne; eklezjologia natchnienia; Ciało Chrystusa; członki Chrystusa; jedność diachroniczna; communio sanctorum. 